\title{
PENGARUH PENGGUNAAN MACROMEDIA FLASH TERHADAP HASIL BELAJAR SISWA MELALUI MODEL PEMBELAJARAN REALISTIC MATHEMATIC EDUCATION PADA MATERI FUNGSI KOMPOSISI KELAS X IIS 3 SMAN 1 NGADILUWIH
}

\author{
Laitali Mala ${ }^{1}$, Fanda R.P. Latif ${ }^{2}$, Hilyatu Zahro, ${ }^{3}$, Linta F. Muftikah ${ }^{4}$ \\ Institut Agama Islam Negeri Tulungagung \\ email: mallaitaa@gmail.com, Fandariza69@gmail.com, zahrohilya7@gamil.com, \\ lintafuadatil.20@gmail.com
}

\begin{abstract}
Abstrak
Penelitian ini bertujuan untuk mengetahui apakah ada pengaruh penggunaan Macromedia Flash melalui model pembelajaran Realistic Mathematic Education terhadap hasil belajar siswa kelas X-IIS 3 pada materi fungsi komposisi. Penelitian ini merupakan jenis penelitian penelitian kuantitatif dengan eksperimen. Penelitian ini dilakukan di SMAN 1 Ngadiluwih, Kediri tahun ajaran 2018/2019 dengan sampel 1 kelas. Pengambilan sampel dilakukan dengan cara Simple Random sampling. Analisis data pada penelitian ini yang pertama adalah menggunakan uji normalitas. Setelah data dinyatakan berdistribusi normal uji selanjutnya adalah uji homogenitas. Uji yang terakhir adalah uji t dua sampel berpasangan, dengan taraf signifikasi sebesar 0,05. Dari hasil uji tersebut diperoleh $\mathrm{t}=-4,324$, dengan $\mathrm{df}=28$ dan angka sig. atau p-value $=0,000<0,05$ atau $H_{0}$ ditolak yang artinya terdapat perbedaan hasil belajar fungsi komposisi siswa antara sebelum dan sesudah diberi Macromedia Flash. Sehingga dapat dikatakan ada pengaruh penggunaan Macromedia Flash melalui model Realistic Mathematic Education terhadap hasil belajar siswa kelas X-IIS 3 SMAN 1 Ngadiluwih Kediri pada materi fungsi komposisi.
\end{abstract}

Kata Kunci: Macromedia Flash, Realistic Mathematic Education (RME)

\section{PENDAHULUAN}

Interaksi antara guru dengan siswa saat proses pembelajaran sangatlah berperan penting dalam mencapai suatu tujuan yang diharapkan. Tujuan tersebut terkendala karena ada beberapa faktor yang membuat siswa kurang aktif dan kurang berprestasi serta mendapat nilai yang kurang dari KKM, (Dewi, 2017) diantaranya 1) siswa 
kurang aktif dalam proses belajar di kelas, dan 2) semangat siswa umtuk belajar masih kurang. Faktor lain selain yang disebut di atas yaitu peran guru sangatlah penting untuk keberhasilan siswanya. Guru matematika seringkali hanya monoton menggunakan metode ceramah saja, kemudian menyuruh siswa hanya duduk mendengarkan penjelasan, diam, mencatat, dan kemudian diminta memahami. Pola penyampaian guru yang tidak berarah seperti ini membuat siswa mengalami kesulitan dalam belajar, mengingat dalam proses pembelajaran melibatkan siswa hanya untuk mendengarkan, menulis, membaca, mempresentasikan, diskusi kecil, kemudian mengkomunikasikan dengan temannya tentang masalah yang disampaikan guru baik masalah kontekstual maupun masalah yang abstrak (hanya suatu operasi).

Untuk mengatasi masalah diatas, salah satu alternatif caranya adalah dengan penggunaan media dan model pembelajaran untuk menarik dan mamacu siswa untuk ikut serta aktif dalam proses pembelajaran. Media dan model pembelajaran yang dimaksud disini adalah Macromedia Flash dan model pembelajaran Realistic Mathematic Education/RME (Sakti, dkk., 2012). Macromedia Flash adalah suatu aplikasi yang digunakan untuk mengolah gambar dan animasi. Objek yang dapat diolah untuk membuat animasi dalam Macromedia Flash adalah gambar vektor, objek sound, dan objek avi serta dapat juga menghasilkan animasi untuk suatu web, presentasi maupun film. Kelebihan dari Macromedia Flash adalah termasuk aplikasi yang menarik, ukuran filenya kecil dengan kualitas yang baik, Hardware nya tidak tinggi, dan dapat membuat situs animasi website. (Sakti, dkk., 2012)

Model pembelajaran Realistic Mathematic Education adalah suatu model pembelajaran matematika dimana matematika harus dihubungkan dengan keadaan sosial dan mengaitkan dengan aktivitas seseorang dalam kehidupan sehari-hari. Matematika sebagai aktivitas seseorang dalam kehidupan sehari-hari maksudnya manusia harus dapat memberikan kesempatan untuk menemukan kembali ide dan konsep dimana digunakan untuk proses kehidupan. 
Berdasarkan penelitian sebelumnya oleh Hudzaifah (2006) yang berjudul Pembelajaran Fungsi Komposisi dan Fungsi Invers Melalui Pendekatan Matematika Realistik untuk Meningkatkan Hasil Belajar Siswa SMA, kami selaku peneliti merasa perlu untuk melakukan penelitian ini dengan tujuan untuk mengetahui apakah ada pengaruh penggunakan media Macromedia Flash terhadap hasil belajar melalui model pembalajaran Realistic Mathematic Education pada materi Fungsi siswa kelas X-IIS 3 SMAN 1 Ngadiluwih tahun ajaran 2018/2019.

\section{METODE PENELITIAN}

Jenis penelitian yang digunakan adalah penelitian kuantitatif karena data yang digunakan berupa angka-angka dan analisisnya menggunkan perhitungan statistik (Segitiga, 2018). Penelitian dilakukan di SMAN 1 Ngadiluwih, Kediri dengan populasi seluruh siswa kelas X IIS dan sampel yang diambil adalah siswa kelas X IIS 3. Pengambilan sampel dilakukan dengan cara Simple random Sampling. Metode yang digunakan dalam penelitian ini adalah menggunakan pre-test dan post-test. Siswa diberikan pre-test sebelum masuk pembelajaran dengan menggunakan Macromedia Flash dan post-test diberikan di akhir, setelah proses pembelajaran menggunakan Macromedia Flash dengan menggunakan model Realistic Mathematic Education. Penelitian ini digunakan untuk menguji hubungan variabel bebas (Macromedia Flash) dengan variabel terikat (hasil belajar siswa).

\section{HASIL DAN PEMBAHASAN}

Setelah data berhasil dikumpulkan, dilakukan uji statistik yang pertama yaitu melakukan uji normalitas. Uji normalitas digunakan untuk mengetahui jenis statistik yang dilakukan selanjutnya. Salah satu alat uji yang sering digunakan untuk mengetahui data berdistribusi normal atau tidak adalah menggunakan uji Kolmogorov-Smirnov atau biasa disebut dengan uji Z. Dengan menggunakan uji 
Kolmogorov-Smirnov dapat ditentukan hipotesis untuk uji normalitas dengan $H_{0}$ : data berdistribusi normal dan $H_{1}$ : data berdistribusi tidak normal. Berikut uji normalitas terhadap data pre-test dan post-test yaitu:

1. Uji normalitas terhadap data pre-test menghasilkan $D_{\text {hitung }}$ sebesar 0,135 dan $\mathrm{D}_{\text {tabel }}$ sebesar 0,25. Berdasarkan Aturan pengambilan keputusan, jika $D_{\text {hitung }}>$ $D_{\text {tabel }}=$ tolak $H_{0}$ dan jika $D_{\text {hitung }} \leq D_{\text {tabel }}=$ terima $H_{0}$. Dari hasil diatas dapat diketahui bahwa $0,135 \leq 0,25$ sehingga $D_{\text {hitung }} \leq D_{\text {tabel }}$ Jadi $H_{0}$ diterima. Oleh karena itu dapat disimpulkan bahwa data pre-test berdistribusi normal.

2. Uji normalitas terhadap data post-test menghasilkan $D_{\text {hitung }}$ sebesar 0,153 dan $\mathrm{D}_{\text {tabel }}$ sebesar 0,25. Dari hasil diatas dapat diketahui bahwa 0,153 $\leq 0,25$ sehingga $D_{\text {hitung }} \leq D_{\text {tabel }}$. Jadi $H_{0}$ diterima, oleh karena itu dapat disimpulkan bahwa data post-test berdistribusi normal.

Dibawah ini uji normalitas menggunakan perhitungan SPSS

\begin{tabular}{|c|c|c|}
\hline & & sebelum \\
\hline \multicolumn{2}{|l|}{$\mathrm{N}$} & 29 \\
\hline \multirow[t]{2}{*}{ Normal Parameters ${ }^{a}$} & Mean & 56.90 \\
\hline & Std. Deviation & 27.562 \\
\hline \multirow[t]{3}{*}{ Most Extreme Differences } & Absolute & .133 \\
\hline & Positive & .117 \\
\hline & Negative & -.133 \\
\hline Kolmogorov-Smirnov z & & .716 \\
\hline Asymp. Sig. (2-tailed) & & 685 \\
\hline
\end{tabular}

Hipotesis yang akan diuji adalah

$\mathrm{H}_{0}$ : distribusi populasi normal, jika probabilitas $>0,05$

$\mathrm{H}_{1}$ : distribusi populasi tidak normal, jika probabilitas $\leq 0,05$

Berdasarkan tabel uji normalitas di atas pada baris Asymp.Sig. (2-tailed) sebesar 0,685 atau nilai probabilitas $\left(\mathrm{p}\right.$-value) $=0,685>0,05$ atau $\mathrm{H}_{0}$ diterima. Dengan demikian data sebelum menggunakan media flash melalui model Realistic 
Mathematic Education berdistribusi normal.

\begin{tabular}{|c|c|c|}
\hline & & sesudah \\
\hline N & & 29 \\
\hline \multirow[t]{2}{*}{ Normal Parameters ${ }^{a}$} & Mean & 67.24 \\
\hline & Std. Deviation & 19.575 \\
\hline \multirow[t]{3}{*}{ Most Extreme Differences } & Absolute & .156 \\
\hline & Positive & .156 \\
\hline & Negative & -.094 \\
\hline Kolmogorov-Smirnov $Z$ & & .838 \\
\hline Asymp. Sig. (2-tailed) & & .484 \\
\hline
\end{tabular}

Hipotesis yang akan diuji adalah

$\mathrm{H}_{0}$ : distribusi populasi normal, jika probabilitas $>0,05$

$\mathrm{H}_{1}$ : distribusi populasi tidak normal, jika probabilitas $\leq 0,05$

Berdasarkan tabel uji normalitas di atas pada baris Asymp.Sig. (2-tailed) sebesar 0,484 atau nilai probabilitas $\left(\mathrm{p}\right.$-value) $=0,484>0,05$ atau $\mathrm{H}_{0}$ diterima. Dengan demikian data setelah menggunakan Macromedia Flash melalui model Realistic Mathematic Education berdistribusi normal.

Berdasarkan uji Kolmogorov-Smirnov dapat diketahui bahwa data pre-test dan post-test berdistribusi normal, sehingga jenis statistik dapat dilakukan menggunakan statistik parametrik. Langkah selanjutnya yang dilakukan adalah dengan melakukan uji homogenitas. Uji homogenitas ini untuk mengetahui data pre-test dan post-test yang diperoleh bersifat homogen atau tidak.

Uji homogenitas dilakukan dengan memisalkan $S_{1}$ sebagai pre-test dan $S_{2}$ sebagai post-test sehingga dapat ditentukan hipotesis yaitu, $H_{0}: S_{1}{ }^{2}=S_{2}{ }^{2}$ dan $H_{1}$ : $S_{1}{ }^{2} \neq S_{2}{ }^{2}$. Rumus yang digunakan dalam uji homogenitas adalah $r_{12}=\frac{\sum Y_{1} Y_{2}}{\sqrt{\left(\sum Y_{1}{ }^{2}\right)\left(\sum Y_{2}{ }^{2}\right)}}$ dengan rumus $t_{\text {hitung }}=\frac{\left|S_{1}{ }^{2}-S_{2}{ }^{2}\right|}{2 S_{1} S_{2} \sqrt{\frac{1-r_{12}}{d b}}}$. Dari kedua rumus tersebut diperoleh $r_{12}=$ 0,975 dan $t_{\text {hitung }}=0,175$ serta $t_{\text {tabel }}=2,052$ sehingga diperoleh 


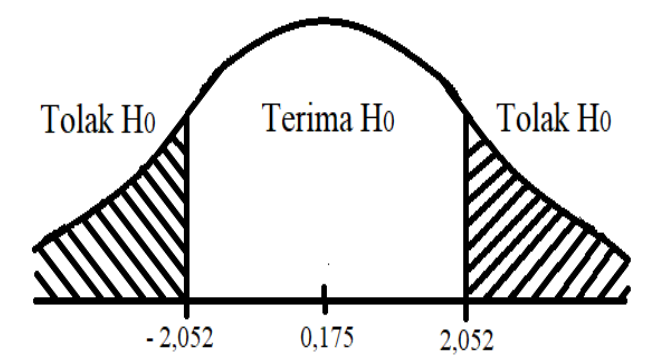

Dengan demikian kesimpulannya adalah terima $H_{0}: S_{1}{ }^{2}=S_{2}{ }^{2}$, jadi data pre-test dan post-test merupakan data yang bersifat homogen.

Karena data bersifat homogen maka langkah selanjutnya adalah uji t 2 sampel berpasangan. Hipotesis untuk uji t 2 sample berpasangan adalah:

$H_{0}$ : Ada beda hasil belajar sebelum dan sesudah penggunaan media flash

$H_{1}$ : tidak ada beda hasil belajar sebelum dan sesudah penggunaan media flash Atau dapat ditulis:

$H_{0}: \mu_{1}=\mu_{2}$

$H_{1}: \mu_{1} \neq \mu_{2}$

Dengan menggunakan rumus $t_{\text {hitung }}=\frac{\overline{Y_{1}}-\overline{Y_{2}}}{\sqrt{\frac{\sum d^{2}}{n(n-1)}}}$ diperoleh $t_{\text {hitung }}=-4,324$ dan $t_{\text {tabel }}=2,048$ sehingga diperoleh

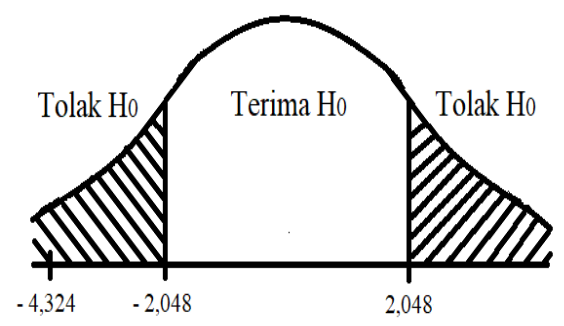


Di bawah ini adalah uji t 2 sampel berpasangan menggunakan perhitungan SPSS

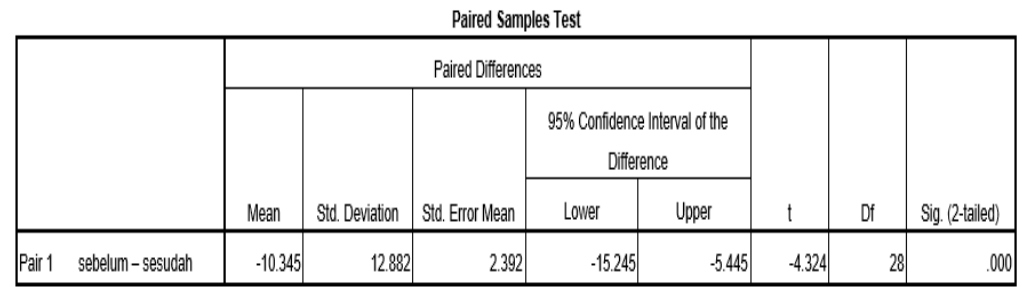

Pada tabel paired samples Test di atas, diperoleh harga statistik $\mathrm{t}=-4,324$, dengan $\mathrm{df}=28$ dan angka sig. atau p-value $=0,000<0,05$ atau $H_{0}$ ditolak. Dengan demikian, dapat dikatakan bahwa terdapat perbedaan hasil belajar matematika materi fungsi komposisi siswa antara sebelum dan sesudah diberi media flash. Sehingga media flash melalui model Realistic Mathematic Education berpengaruh terhadap hasil belajar siswa pada materi fungsi komposisi kelas X SMAN 1 Ngadiluwih.

\section{KESIMPULAN DAN SARAN}

Dari hasil penelitian dan analisis data yang sudah dilakukan maka diperoleh kesimpulan sebagai berikut :

1. Sebelum menggunakan media flash dan sesudah menggunakan media flash melalui model pembelajaran Realistic Education Mathematic ada pengaruh terhadap hasil belajar siswa.

2. Hasil belajar siswa mengalami peningkatan dari sebelum menggunakan media flash dan sesudah menggunakan media flash melalui model pembelajaran Realistic Education Mathematic

Berdasarkan hasil penelitian dan kesimpulan, peneliti memberikan saran bahwa karena adanya peningkatan hasil belajar siswa menggunakan media flash melalui model Realistic Mathematic Education maka guru dapat menggunakan media ini sebagai cara untuk meningkatkan hasil belajar siswa. Bagi peneliti lain yang mengkaji kasus yang sama, bisa mengembangkan lagi penelitiannya. 


\section{REFERENSI}

Hudzaifah. (2006). Pembelajaran Fungsi Komposisi dan Fungsi Invers Melalui Pendekatan Matematika Realistik untuk Meningkatkan Hasil Belajar Siswa SMA, 397-403.

Sakti, I., Puspasari, Y. M., \& Risdianto, E. (2012). Pengaruh Model Pembalajaran Langsung. Pengaruh Model Pembalajaran Langsung (Direct Instruction) Melalui Media Animasi Berbasis Macromedia Flash Terhadap Minat Belajar Dan Pemahaman Konsep Fisika Siswa Di SMA Plus Negeri 7 Kota Bengkulu, $X(1), 1-10$.

Segitiga, S. D. A. N. (2018). Korelasi Kecerdasan Numerik dan Pemahaman Konseptual Matematika Terhadap Hasil Belajar Siswa dalam Menyelesaikan Masalah Segiempat dan Segitiga, 3, 3-6. 